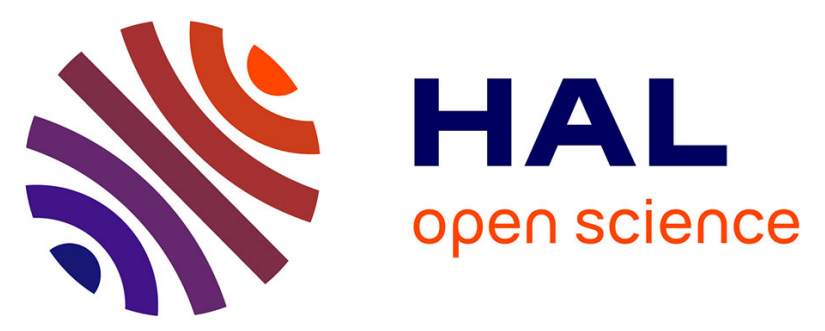

\title{
Was the rise of TB contemporaneous with the industrial revolution? Epidemiological evolution of TB in France (17th-20th centuries) inferred from osteoarchaeological and historical archives
}

\author{
Olivier Dutour, Antony Colombo, Hélène Coqueugniot
}

\section{To cite this version:}

Olivier Dutour, Antony Colombo, Hélène Coqueugniot. Was the rise of TB contemporaneous with the industrial revolution? Epidemiological evolution of TB in France (17th-20th centuries) inferred from osteoarchaeological and historical archives. International Journal of Paleopathology, 2021, 34, pp.130-133. 10.1016/j.ijpp.2021.04.005 . hal-03376670

\author{
HAL Id: hal-03376670 \\ https://hal.science/hal-03376670
}

Submitted on 13 Oct 2021

HAL is a multi-disciplinary open access archive for the deposit and dissemination of scientific research documents, whether they are published or not. The documents may come from teaching and research institutions in France or abroad, or from public or private research centers.
L'archive ouverte pluridisciplinaire HAL, est destinée au dépôt et à la diffusion de documents scientifiques de niveau recherche, publiés ou non, émanant des établissements d'enseignement et de recherche français ou étrangers, des laboratoires publics ou privés. 


\section{Title}

Was the rise of TB contemporaneous with the Industrial Revolution?

Epidemiological evolution of TB in France (17th-20th centuries) inferred from osteoarchaeological and historical archives

\section{Authors name and affiliations:}

Olivier DUTOUR ${ }^{1,2,4}$, Antony COLOMBO ${ }^{1,2}$, Hélène COQUEUGNIOT ${ }^{1,2,3}$

1 - Chaire d'Anthropologie biologique, EPHE-PSL University, Paris, France

2 - UMR 5199 PACEA, CNRS/University of Bordeaux/Ministry of Culture, Pessac, France

3 - Department of Human Evolution, Max Planck Institute for Evolutionary Anthropology, Leipzig, Germany

4 - Department of Anthropology, Canada Social Science Centre, Western University, London, ON, Canada

\section{Corresponding author:}

Olivier Dutour

olivier.dutour@ephe.psl.fr

\section{ORCID :}

Olivier Dutour - 0000-0001-8134-788X

Hélène Coqueugniot - 0000-0002-1844-4588

Antony Colombo - 0000-0002-8855-7502 


\section{Abstract}

Objective: The development of tuberculosis is classically associated with the rise of the Industrial Revolution. Our objective is to test this epidemiological hypothesis for populations in France between the 18th and 20th centuries using osteoarchaeological and historical sources.

Materials: Osteoarchaeological sources include two skeletal collections from plague epidemics in Provence (1590 and 1722) representing a total of 349 individuals and medical archives dating 1750 to 1930 from Paris, Lyon, Marseille, Montpellier.

Methods: Paleoepidemiological analysis (crude prevalence rate) of the archeological data, and epidemiological analysis of historical data included the proportional mortality rate of tuberculosis (PMR-TB) and the mortality rate by tuberculosis (MR-TB).

Results: Mean prevalence of TB before the $19^{\text {th }}$ century was approximately $30 \%$, according to osteoarchaeological data. Historical sources showed that pulmonary TB was responsible for $33 \%$ of total deaths in the city of Marseille during the second half of the $18^{\text {th }}$ century and represented about $20 \%$ of deaths in the four French cities during the $19^{\text {th }}$ century. The mortality rate was 6.5 per thousand inhabitants in the $18^{\text {th }}$ century (Marseille) and stable at 4 to $5 \%$ during the $19^{\text {th }}$ century before, during, and after the Industrial Revolution period, with the exception of years 1870-1871 (French-Prussian war), when it increased.

Conclusions: Population increase contemporary to the industrialization process did not increase the mortality rate by tuberculosis in France.

Significance: The epidemiological assertion that tuberculosis increased with the Industrial Revolution in cities must be reevaluated. In France, and perhaps in other cities, it was an endemic disease at least a century before, and associated with a higher mortality rate.

Limitations: Reliability and biases inherent to archaeological and historical data prior and during the Industrial Revolution must be taken into account.

Suggestions for further research: Extension of research to all the French territories (rural and urban areas) is advised.

Keywords: paleoepidemiology ; cities ; Paris ; Marseille ; Lyon ; Montpellier

Abstract à 250 mots :

Objective: We tested the epidemiological hypothesis associating the rise of Industrial Revolution with the development of tuberculosis in France (17th-20th centuries) using osteoarchaeological and historical sources.

Materials: We analyzed two skeletal collections from plague epidemics in Provence (1590 and 1722; 349 individuals) and medical archives (1750-1930) from 4 main French cities.

Methods: Paleoepidemiological analysis (crude prevalence rate CPR) and epidemiological analysis (proportional mortality rate PMR-TB and mortality rate MR-TB). 
Results: Mean prevalence of TB before the $19^{\text {th }}$ century was approximately $30 \%$ (osteoarchaeological data). Pulmonary TB was responsible for $33 \%$ of total deaths in Marseille (late $18^{\text {th }}$ century); it represented $20 \%$ of deaths in the four French cities during the $19^{\text {th }}$ century. The mortality rate was $6.5 \%$ in the $18^{\text {th }}$ century (Marseille) and stable at $4-5 \%$ during the $19^{\text {th }}$ century before, during, and after the Industrial Revolution period, with the exception of years 1870-1871 (French-Prussian war), when it increased.

Conclusions: Population increase contemporary to the industrialization process did not increase the mortality rate by tuberculosis in France.

Significance: The epidemiological assertion that tuberculosis increased with the Industrial Revolution in cities must be reevaluated. In France, and perhaps in other cities, it was an endemic disease at least a century before, and associated with a higher mortality rate.

Limitations: Reliability and biases inherent to archaeological and historical data prior and during the Industrial Revolution must be taken into account.

Suggestions for further research: Extension of research to all the French territories (rural and urban areas) is advised. 


\section{Introduction}

Tuberculosis is considered to have been the infectious disease of the 19th century, popularized in romantic literature (Daniel, 2006; Frith, 2014). It is widely asserted that tuberculosis reached its full extent in Western Europe with the Industrial Revolution. This resulted from population growth in urban areas associated with poor socioeconomic conditions, malnutrition, and overcrowding; all factors closely linked to the spread of the infection (Barberis et al., 2017; Cottereau, 1978; Komlos, 1990; Murray, 2015). Can this statement be supported epidemiologically? In order to answer this question, both osteoarcheological and historical data available for France dating from the 16th to the early 20th centuries were evaluated using paleoepidemiological and historical epidemiological analyses. The goal of this study was to determine if the rise of tuberculosis was contemporaneous with the Industrial Revolution and urbanization in France beginning in 1830.

\section{Material}

Our data is derived from archeological (human remains) and historical sources (medical archives). The archeological sources were used to explore the prevalence of skeletal TB before the Industrial Revolution. Human skeletal remains from historical plague mass graves were chosen, as their demographic structure is closer to the living population and are theoretically less biased than classical osteoarcheological series when reconstructing past prevalence of diseases (Dutour et al., 2007). Two mass graves, discovered in Provence, were available for this study: the cemetery of the plague infirmary "Les Fédons" dated from 1590, which provided 133 skeletons of plague victims (Bouttevin et al., 2007), and the mass grave of the plague hospital of "L'Observance", dated from 1722, where 216 skeletons were recovered (Dutour et al., 1994). The historical sources derived from medical archives, are represented by monthly and weekly periodicals, urban hospital records and medical books. They report on the epidemiology of tuberculosis in France from the end of the $18^{\text {th }}$ century to the beginning of the $19^{\text {th }}$ century in four major cities: Paris, Lyon, Marseille and Montpellier (Bello et al., 1999).

\section{Methods}

Archeological data were analyzed paleoepidemiologically (Dutour, 2008; Waldron, 2007) using crude prevalence rate ( $C P R=n u m b e r$ of cases / number of skeletons preserved). The diagnosis of skeletal tuberculosis was made based on morphological and radiological criteria, with molecular confirmation (Zink et al., 2001). The conversion from skeletal TB prevalence (crude prevalence rate, CPR) to general prevalence of active TB relied on Resnick's data for frequency of skeletal tuberculosis. Resnick asserts that between $3 \%$ to $5 \%$ of active cases of TB will result in skeletal involvement (Resnick and Niwayama, 1988). Currently, about $30 \%$ of the world's population harbors latent TB infection (LTBI), and among these individuals, 5\% will develop an active TB infection (Albanese et al., 2015). We did not use lower values proposed by Davidson and Horowitz (1970) that, when tested, provided inconsistent prevalence estimates.

Historical data were collected in the archives of medical libraries, which report data on illness and death due to TB (Bello et al., 2000). As the name of the disease has evolved with scientific and medical knowledge, inclusion was restricted to the terms "pulmonary phtisia", "haemoptysis" and "pulmonary tuberculosis". This strict selection focussed on the pulmonary form of TB infection and ruled out other cases of active tuberculosis, pulmonary or extra-pulmonary, particularly in the oldest documents. However, this selection ensures greater diagnostic reliability. We used two epidemiological indicators: the proportional mortality rate of tuberculosis (PMR-TB), which is the death toll due to TB out of the total number of deaths, and the mortality rate of tuberculosis (MR-TB), which indicate, by year, the annual number of deaths due to TB based on population size. 


\section{Results}

\subsection{Prevalence of active TB in France before 1830 derived from skeletal data}

Based on the analysis of 133 skeletons from the rural Provence cemetery of the plague infirmary "Les Fédons" dated from 1590, the prevalence of active TB is estimated to have ranged between 15 to $25 \%$ (based on assumed proportion of 3 to $5 \%$ of TB cases, out of all active TB cases within the population, will result in skeletal involvement). We diagnosed one case of TB spondylodiscitis out of 133 skeletons (CPR $=0.75 \%)$. In the mass grave of the plague hospital of "L'Observance", dated to 1722 , located in a working-class neighborhood of the city of Marseilles, the prevalence was estimated between 28 to $46 \%$ (three cases out of 216 individuals, CPR=1.39\%). From these skeletal data, we can assume that TB infection rate ranged from 15 to $46 \%$ before the $19^{\text {th }}$ century. We can therefore assume that the prevalence of tuberculosis infection was already high in France before the Industrial Revolution.

4.2 Pulmonary TB before, during, and after the Industrial Revolution

Based on historical archival data dating from 1750 to 1776, pulmonary TB was responsible for $33 \%$ of the deaths in the city of Marseille (Figure 1). This proportion dropped to $20 \%$ by 1800 and remained constant at around $20 \%$ of deaths in the urban centers of Paris, Lyon, Marseille and Montpellier, from 1800 to 1900, before, during and after the Industrial Revolution period. The rate dropped to 9\% by 1950 and reached its present level of $0.001 \%$ in 2000 . Thus, it appears that there was no increase in tuberculosis mortality during the Industrial Revolution, but rather, a reduction in the number of deaths due to tuberculosis relative to other causes of death.

Evaluating the mortality rate from 1750 to 1776 in the city of Marseille, it appears that TB was responsible for the deaths 6.5 per 1,000 inhabitants (Figure 1). This rate can be extended from 1810 to 1934 in the four major French cities: Paris, Lyon, Marseille and Montpellier. For these cities, the mortality rate remains stable at 4 to $5 \%$ during the period 1810-1900, except during the years 1870 1871 , which corresponds to the French-Prussian war. During this brief period, the mortality rate increased to above 6.5/1000, comparable to the rate observed in the second part of the $18^{\text {th }}$ century. After 1920, the rate decreased dramatically. Clearly, the mortality rate from pulmonary TB in French cities decreased prior to the Industrial Revolution. The exception to this pattern occurs during unique events including 1870-1871 French-Prussian war, and the siege of Paris (September 1870-January 1871) and the civil war (March-May 1871), when the MR-TB increased at a rate comparable to the one seen in the $18^{\text {th }}$ century. 


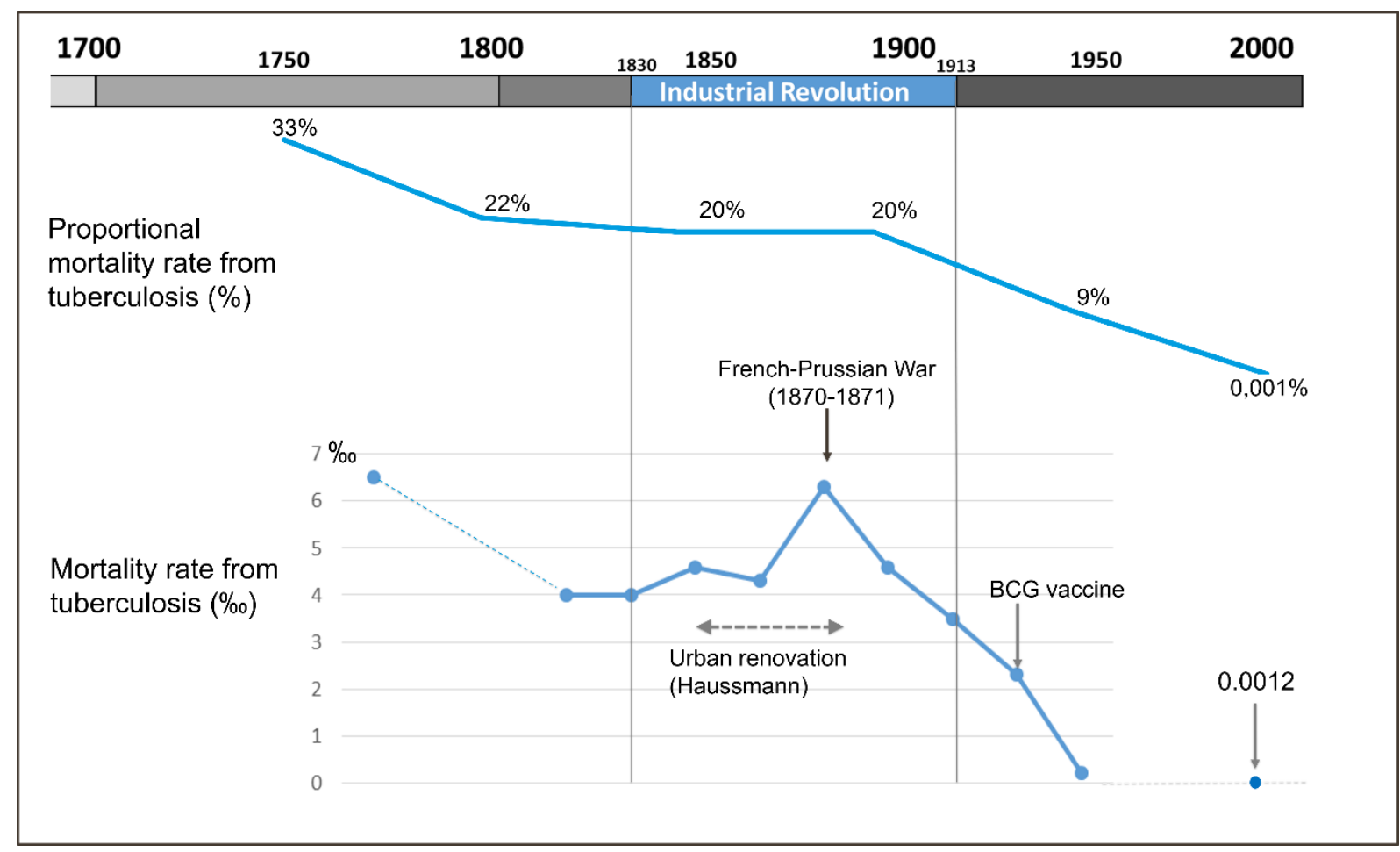

Figure 1: Evolution of the proportional mortality rate and the mortality rate from tuberculosis (historic data) through the mid $18^{\text {th }}$ to the $20^{\text {th }}$ centuries in French urban areas (Paris, Lyon, Marseille, Montpellier) before, during, and after the Industrial Revolution (1830-1913). Prior to the introduction of BCG vaccine, the decline of PMR and MR from tuberculosis followed the vast urban renovation program undertaken during the Second French Empire (1850-1870) and headed by Baron Haussmann.

\section{Discussion}

Once the methodological biases in paleoepidemiology (state of preservation of skeletons, structure and nature of samples, difficulties of diagnosis, etc.) and in historical epidemiology (lack of records, inaccuracies or diagnostic errors) are addressed, the results obtained underline three main points:

(i) The prevalence of active TB before the $19^{\text {th }}$ century derived from the skeletal data (15$46 \%$ ) is very high when compared to the current worldwide average TB prevalence, but it is plausible. In low-and middle-income countries, the current prevalence of LBTI is about $50 \%$ of the population, and in a household where a member is infected with TB, up to $30 \%$ of contacts will develop active TB (Albanese et al., 2015). For the 18th century, although historical documents did not document directly active TB prevalence rate, the other two indicators PMR-TB and MR-TB are consistent to its high values.

(ii) Tuberculosis was already an active infection in France before the beginning of the Industrial Revolution, which started in the country in 1830, almost a century later than in England. Caution is needed when interpreting the prevalence rates from osteological data, as these rates reflect calculated infection rates, not the mortality rates recorded in historical documents. Nevertheless, the osteological data show the active and frequent presence of TB within the populations, at least since the 16th century. The mortality rates observed in the historical data reinforce this result. In the second half of the 18th 
century, tuberculosis accounted for a third of the recorded causes of death, a number that dropped to $20 \%$ at the beginning and during the Industrial Revolution in France (1810-1913). If this result was due simply to the fact that during the Industrial Revolution, the expansion of tuberculosis was masked by an increase in other causes of mortality (other infections such as cholera, traumatic risks associated with industrialization, severe under-nutrition in the poor classes), tuberculosis mortality relative to the number of inhabitants should increase. However, this rate decreased from the one observed in the 18th century, remaining stable throughout the Industrial Revolution in France, except in 1870-1871, which were years severely disrupted by military war, accompanied by siege and famine, civil war, and major political and socioeconomic crisis.

(iii) The rapid decrease in tuberculosis mortality following the Industrial Revolution, which is a general trend observed worldwide (Anderson, 1993; Murray, 2015) started in France at the very beginning of the 20th century according to our data, and well before the introduction of vaccination by BCG. This might be due to improvement of housing that marked the massive urban renewal program headed by Baron Haussmann (from the late 1850 s to the 1870s in Paris, followed by the other major French cities).

The demographic transition, which was characterized by population growth coinciding with the industrialization process (Komlos, 1990) did not increase the mortality rate from tuberculosis in France, but rather remained stable during this period and decreased dramatically at its end.

\section{Conclusion}

To conclude, our results did not confirm that tuberculosis increased with the Industrial Revolution in France. It seems it was already an endemic disease at least a century before, with a higher mortality rate. The French data present evidence contrary to the general assumption that tuberculosis was a pathological consequence of industrialization and urbanization (both started in 1830). In the case of France, it was during the Industrial Revolution that tuberculosis began its epidemiological transition characterized by a marked reduction in mortality.

\section{References}

Albanese, S.P.R., Costa, A.A.N.F. da, Pieri, F.M., Alves, E., Santos, D.T. dos, Kerbauy, G., Arcêncio, R.A., Dessunti, E.M., 2015. Prevalence and evolution of Mycobacterium tuberculosis infection in tuberculosis case contacts. Rev. Soc. Bras. Med. Trop. 48, 307-313. https://doi.org/10.1590/00378682-0014-2015

Anderson, I., 1993. The decline of mortality in the nineteenth century: with special reference to three English towns (MA). Durham University, Durham.

Barberis, I., Bragazzi, N.L., Galluzzo, L., Martini, M., 2017. The history of tuberculosis: from the first historical records to the isolation of Koch's bacillus. Journal of Preventive Medicine and Hygiene 58, E9-E12. 
Bello, S., Signoli, M., Maczel, M., Dutour, O., 1999. Evolution of mortality due to tuberculosis in France (18-20th centuries), in: Pálfi, G., Dutour, Olivier, Deák, J., Hutás, I. (Eds.), Tuberculosis: Past and Present. Golden Book Publishers and Tuberculosis Foundation, Budapest/Szeged, pp. 95-104.

Bello, S., Signoli, M., Dutour, O., 2000. Tuberculosis mortality in France from the 18th to 20th century. Analyse de l'évolution de la mortalité par tuberculose du XVIIle au XXe siècle dans quatre grandes villes françaises. Médecine et Maladies Infectieuses 30, 275-283.

Bouttevin, C., Signoli, M., Ardagna, Y., Dutour, O., 2007. Le cimetière des Fédons (Lambesc, Bouchesdu-Rhône) : données paléopathologiques, in: Signoli, M., Chevé, D., Adalian, P., Boetsch, G., Dutour, O. (Eds.), La Peste : Entre Épidémies et Sociétés. Firenze University Press, Firenze, pp. 71-76.

Cottereau, A., 1978. La tuberculose : maladie urbaine ou maladie de l'usure au travail ? Critique d'une épidémiologie officielle : le cas de Paris. sotra 20, 192-224.

https://doi.org/10.3406/sotra.1978.1574

Daniel, T.M., 2006. The history of tuberculosis. Respiratory Medicine 100, 1862-1870. https://doi.org/10.1016/j.rmed.2006.08.006

Davidson, P.T., Horowitz, I., 1970. Skeletal tuberculosis. The American Journal of Medicine 48, 77-84. https://doi.org/10.1016/0002-9343(70)90101-4

Dutour, O., 2008. Archaeology of Human Pathogens: Palaeopathological Appraisal of Palaeoepidemiology, in: Raoult, D., Drancourt, M. (Eds.), Paleomicrobiology. Springer Berlin Heidelberg, Berlin, Heidelberg, pp. 125-144. https://doi.org/10.1007/978-3-540-75855-6_8

Dutour, O., Maczel, M., Ardagna, Y., 2007. Intérêt du modèle peste en paléoépidémiologie, in: Signoli, M., Chevé, D., Adalian, P., Boetsch, G., Dutour, Olivier (Eds.), Peste: entre épidémies et sociétés. Firenze University Press, Firenze, pp. 101-108.

Dutour, O., Signoli, M., Georgeon, E., Da Silva, J., 1994. Le charnier de la Grande Peste de Marseille (rue Leca): données de la fouille de la partie centrale et premiers résultats anthropologiques. Préhistoire anthropologie méditerranéennes 3, 191-203.

Frith, J., 2014. History of Tuberculosis. Part 1 - Phthisis, consumption and the White Plague 22, 7.

Komlos, J., 1990. Nutrition, Population Growth, and the Industrial Revolution in England. Social Science History 14, 69. https://doi.org/10.2307/1171364

Murray, J.F., 2015. The Industrial Revolution and the decline in death rates from tuberculosis. International Journal of Tuberculosis and Lung Diseases 19, 2. https://doi.org/10.5588/ijtld.14.0856

Resnick, D., Niwayama, G., 1988. Diagnosis of bone and joint disorders Second edition Volumes 1-6. WB Saunders Co, United States.

Waldron, T., 2007. Palaeoepidemiology: the measure of diseases in the human past. Left Coast Press, Walnut Creek, Calif.

Zink, A., Signoli, M., Ardagna, Y., Maczel, M., Dutour, O., Nerlich, A., 2001. Molecular evidence for tuberculosis in vertebral bone tissue of burals of a plague cemetery, in: Signoli, M., Chevé, D., Adalian, P., Boetsch, G., Dutour, O. (Eds.), Peste: entre épidémies et sociétés. Firenze University Press, Firenze, pp. 287-290. 
Acknowledgements: The authors would like to express their warmest thanks to Dr. Jo Buckberry and Dr. Gillian Crane-Kramer, the organizers of the special session and guest editors of this Virtual Special Issue for the International Journal of Paleopathology. They are also deeply grateful to the two reviewers and the Editor for their comments and editing suggestions which have greatly improved our manuscript.

Funding: This work was partially supported by the Cluster of Excellence in Archaeological Sciences in Bordeaux (grant number ANR-10-LABX-52). 